\title{
The Influence Of Application Technology,Firms Size, and Strategy of Operating Performance of Micro, Small and Medium Enterprises
}

\author{
Ratna Anggraini \\ Department of Accounting, Faculty of Economics, State University of Jakarta, Jakarta, Indonesia
}

\author{
Nuramalia Hasanah \\ Department of Accounting, Faculty of Economics, State University of Jakarta, Jakarta, Indonesia
}

Corresponding Author: Ratna Anggraini, Department of Accounting, Faculty of Economics, State University of Jakarta, Jakarta, Indonesia. Tel:+6221-4721227, Fax: +62214706285, E-mail: r.anggrainizr_unj@yahoo.com

Received date: 23 March 2018, Accepted date: 28 May 2018, Online date: 18 June 2018

Copyright: (c) 2018 Ratna Anggraini, et al. This is an open-access article distributed under the terms of the Creative Commons Attribution License, which permits unrestricted use, distribution, and reproduction in any medium, provided the original author and source are credited.

\begin{abstract}
This study aims to examine the factors affecting operating performance on micro, small and medium enterprises (MSEMs) in East Jakarta, Indonesia. Using independent variables application of technology, firm size, strategy and as dependent variable is operational performance. This research uses purposive sampling technique with total sample 33 MSMES in East Jakarta. The data is collected through a survey instrument. The analytical method used is multiple linear regression. The results of this study indicates that the application of technology and firm size that affect the operational performance, while strategy has no influence on operational performance. The empirical contribution in MSMES, in particular to improve their performance.
\end{abstract}

Key words: Application of Technology ; Firm Size;Strategy; Operational Performance;MSMES

\section{INTRODUCTION}

Contribution Small medium enterprises in Indonesia GDP about 60\% (CNN Indonesia, 2016). As one of the existing business units, MSMES should follow these developments immediately in order to compete even worldwide. MSMES is a vital sector in the growth and economic development both in developed and developing countries because of its role in providing jobs. MSMES have the ability to absorb labors and have a large number of total business units in Indonesia ( Detik finance, 2016). Hill [10] stated that MSMES plays an important role in economic development in Indonesia.

Research on operational performance of SMES conducted by Nehemiah [46] shows the supply chain management practices have a positive effect on SMES operating performance across the sectors of trade and information technology. Some studies that specifically discuss the operational performance of SMES conducted by Njenga (2015) found that innovation was widely practiced in SMES. Some factors such as employee training programs, competitive pressures and market segments served were identified to have a large influence on adoption of innovation. The study also established that innovation discovered while improving operational performance in the practicing firms. While Hsueh and Tu stated that the innovation resulted in a positive relationship with operational performance of new enterprises. A study by Moorthy et al., [45] shows that there is a positive and significant relationship between the use of marketing information and information technology applications to SMES performance. On the contrary, ineffective entrepreneurship and inappropriate human resource management (HRM) have a negative and significant influence on performance MSMES. Meanwhile Ashrafi and Murtaza stated that the use of information communication technology can improve the performance of SMES.

Other ascendants affecting the performance of SMES are firm size. In previous studies Jung [26] has shown that firm size influences firm entrepreneurship and SMES longevity performance, but for firm entrepreneurship and SMES variable contribution or profitability performance have no effect against the size of the company in SMES. Other research Raziq [48] claimed that there was a positive relationship between company size and application of high performance management practices in Pakistani SMES.

Another aspect that supports SMES performance is business strategy. Basically, strategy has a positive relationship with business unit performance, however Gibcus and Kemp [21] claimed that strategy does not influence performance. On the other hand, a study by Leitner and Guldenberg [28] at MSMES in Austria stated that there is a difference performance when distinct strategies were applied. MSMES that follow a combination strategy outperform a company without generic strategy in terms of profitability and growth achieve a higher profit rate than companies that follow a differentiation strategy. Based on the background research on the performance of SMES above, it is very relevant in Indonesia, with many obstacles in developing its performance world bank and Hayashi, whereas the contribution of SMES in various sectors of the economy is quite high. The difference of this study with the previous one is by adding independent variables and changing the sample research[20-40].

\section{Problem statement:}

The companies have different activities in order to compete with competitors and generate optimal returns, this will optimize the performance of MSMES. There are still few MSMES who apply technology and serious business strategy design that can lead to success. If MSMES business units have realized the importance of strategy and technology implementation, they will have a better company performance. The study of the application of technology, firm size and strategy of MSMES will confirm that it improves the performance. 
In general, the purpose of this study is to determine the impact of technology implementation, firm size and strategy on MMSMES performance. Specific objectives of this research are as follow:

1. Knowing the effect of application of technology on MSMES operational performance.

2. Knowing the effect of firm size on MSMES operational performance.

3. Knowing the effect of strategy on MSMES operational performance.

Review of Related Literature:

Bastian said that performance is a description of the level of achievement of the implementation of an activity / program / policy in realizing the goals, objectives, mission, and vision of the organization contained in the formulation of strategic scheme (strategic planning) of an organization. Firm performance indicators can be measured by financial and non-financial. The previous studies about financial performance by pervan and visic, and about operation performance. The use of subjectively performance assessment is better than performance indicator which only measured from the finance report.

One way performance measurement in addition to look at the financial aspect is by measuring operational performance. Operational performance can be defined as the performance derived from the activities of creating goods and services offered by consumers Cristianto et al., [5]. In measuring operational performance can be done through multiple measurement dimensions, Measurement of operational performance is measured by some dimensions of measurement, ie cost per unit products, product quality, quality proses, the ability to handle changes in numbers demand, ability to meet cell changes customer era, timely delivery, and delivery capability before time specified Leong et al., [29]. Another study conducted by Prabowo et al., [2] measures operational performance with the objectives, motives of support falicities, competencies, opportunities, standards, and feedback. This study uses operational performance as a measure of company performance, since financial measures can obscure the signs associated with improved performance and innovation activities Kaplan and Norton [27], Rita [33].

\section{Technology:}

Technology can be defined as a collection of devices consisting of machines used as tools, modifications, arrangements, specific skills or procedures used to assist human activities. In applied science, the notion of technology refers to tools and machines that can be utilized to solve real-world problems. The ability of using the technology is one factor that can affect the performance of MSMES Bayarcelik, et al. The application of technology is carried out to develop new products, facilitate planning, process and evaluate the implementation of production factors. As a result, companies seek to reconcile their shared resources and competencies and combine them to accelerate product development and product development tasks or unique technologies. Although according to Gynawali and Park, this is not that easy and involves high costs and risks.

\section{Firms Size:}

Firm size is a value that shows the size of the company. There are various proxies typically used to represent firm size, such as number of employees, total assets, total sales, and market capitalization Ayyagari et al. The size of the company only divided into three categories, namely large companies (large firm), medium companies (medium size) and small firms (small firm). The size of the firm in veronica and utama (2005) is measured from the natural logarithm of the firm's equity market value at the end of the year, for example the number of shares outstanding at the end of the year multiplied by the year end stock market price. In contrast, Nuryaman measures the size of a company using the total log value of the company's sales at the end of the year. In this study, however, firm size was measured using the logarithm of total assets. Total assets are used as a proxy of firm size with the consideration of total company assets which relatively more stable than the amount of sales and market capitalization value. Assets are benchmarks of a scale or scale of a company. Large companies usually have large assets and values. Companies with large assets has reached the maturity stage where the company's cash flow has been positive and is considered to have a good prospect in relatively long period of time, but it also reflects that the company is relatively more stable and able to generate profit compared to companies with a small total of assets.

\section{Strategy:}

According to Stephanie K. Marrus in Husein umar strategy is a process of determining the plans of top leaders that focus on the long-term goals of the organization, accompanied by the preparation of a way or effort how to achieve that goal. Strategy (strategy) can be defined as "objectives" Reich \& Benbasat, [4], "plan" or "planning". While porter declares business strategy, as the main choices that determine the company's positioning in the business area. Hamel and prahalad in Husein umar say that strategy is an incremental (constantly increasing) and continous action and is done based on the viewpoint of what is expected by the customers in the future.

\section{Influence of application of technology on performance:}

Earlier researchers have found empirical evidence to corroborate that firms which use technology performed better than firms that do not use technology. Technology can affect processes, methods, modifications, settings, and solve business problems of MSMES. Based on empirical study, the researcher tries to focus on operational performance, so this research proposes the first hypothesis as follows:

HI : Application of technology affects MSMES operational performance

\section{Influence of company size on performance:}

Past researchers have found empirical evidences to corroborate that firm size affects performance. Monteiro et al., [30] states the size of the company has a significant influence on export performance. Other researchers Pervan and Visic stated that firm size has a weak and positive effect on the profitability of the company. Based on empirical study, the hypothesis as follows:

HI : Firm size affects MSMES operational performance

The Influence of strategy on performance:

Company strategy becomes important enough to improve performance, the empirical evidence can be seen from Maluu and Jakesa which states that high performance is based on a strategy that will strengthen the dynamics of the company. This strategic capability is a critical mechanism between business activity and performance. Strategy can affect processes, methods, modifications, settings, and solve business problems of MSMES. Based on empirical study, this research proposes the hypothesis as follows:

HI : strategy affects MSMES operational performance

\section{Methodology:}

Based on research objectives, framework and hypothesis,this study used a quantitative approach. This research uses quantitative descriptive method, which is done by using certain ways in collecting data, processing and analyzing data with statistical techniques, and taking conclusions with generalizations. The data of this study were obtained by using a questionnaire focused on testing the relationship between the dependent variable and the independent variable. The data obtained will be analyzed by using SPSS with multiple regression analysis (Multiple Regression Analysis). before processed all the data in transformation to the natural logarithm $(\mathrm{Ln})$, so that the data processed number is not too far away..The sample of this research is MSMES in East Jakarta. The reason for choosing the sample is because there are many MSMES in East Jakarta. Determination of sample in this research using purposive sampling method.

The sample criteria that will be used are:

1. The companies are classified as MSME according to the qualification pursuant to the law of the republic of Indonesia number 20 of 2008 .

2. The companies have completed the data on application of technology, firm size and strategy and also the data needed to detect MSMES operational performance.

The sample companies are selected among them obtained 33 samples. The data obtained is limited because some respondents do not use technology in their business units.Operational performance is measured by objectives, motives of support facilities, competencies, opportunities, standards, and feedback [2]. Application of technology is measured from three dimensions: efficiency, effectiveness and flexibility [2]. Firm size can be expressed by using the logarithm of 
Citation: Ratna Anggraini, 2018. Factors Affecting the Operating Performance of Micro, Small and Medium Enterprises. Journal of Applied Sciences Research.,

\section{4(3): 18-22.}

total assets [20].The strategy based on the generic strategy (Focus type) developed modified by porter is measured by cost indicators and others.

\section{Data Analysis and Empirical Result:}

Classic assumption test:

For normality, this research uses P-Plot test. In normality test, it is using plot, showing pattern of dispersion of dots around diagonal line, following diagonal line direction indicating regression model to fulfill assumption of normality test Ghozali; [8], graphic image can be seen figure 1.



Fig. 1: Normality.

Source: Data processed by researcher.

Multikolinearity test result using Variance Inflation Factor (VIF), where there are no variables that produce VIF values greater than 10 . Were, the VIF values for the application of technology, firm size, strategy, are 1.044,3,805 and 3.867, respectively. So it can be concluded there is no, multicollinearity in the regression equation. This study used a scatterplot chart test to see heterocedastic symptoms. The scatterplot image in figure 2 below shows that the points do not form a clear pattern it can be concluded that the regression model in this study does not occur heteroscedasticity [8].

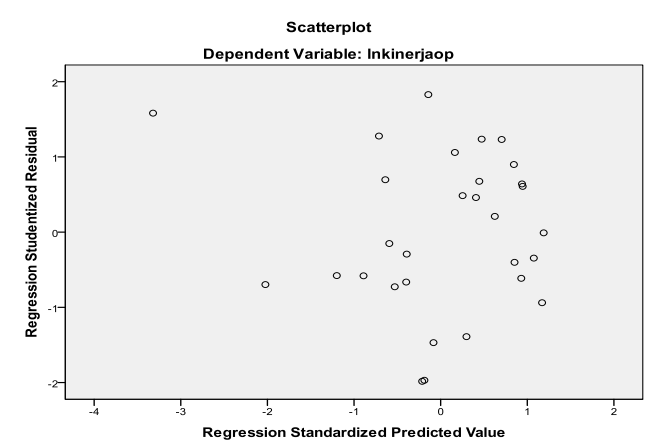

Fig. 2: Heteroscedasticity.

The statistic test is done to determine the influence of each independent variable (individually) to the dependent variable. Based on the test above, it can be concluded as follows:

Tabe l: Hypotesis Testing.

\begin{tabular}{|c|c|c|c|c|c|}
\hline \multirow[t]{2}{*}{ Model } & \multicolumn{2}{|c|}{ Unstandardized Coefficients } & \multirow{2}{*}{\begin{tabular}{|l|} 
Standardized Coefficients \\
Beta
\end{tabular}} & \multirow[b]{2}{*}{$\mathrm{T}$} & \multirow[b]{2}{*}{ Sig. } \\
\hline & $\mathrm{B}$ & Std. Error & & & \\
\hline \begin{tabular}{|l|l|}
1 & (Constant)
\end{tabular} & 1,201 &, 295 & & 4,077 &, 000 \\
\hline LNIT &, 873 & 123 & 1,038 & 7,077 &, 000 \\
\hline LNFS &, 014 &, 005 & 176 & 2,573 &, 015 \\
\hline LNSTRA &,- 121 & 147 &,- 120 &,- 824 &, 417 \\
\hline
\end{tabular}

Table 1.The equation from the data is:

$\mathrm{OP}=1,201+0,873 \mathrm{IT}+0,014 \mathrm{FS}-0,121 \mathrm{ST}$

Information:

$\mathrm{OP}=$ Operating Performance

$\mathrm{IT}=$ Aplication Technology

FS= Firm size

$\mathrm{ST}=$ Strategy

The table also show shows the significance value of application variables of technology (IT) is smaller than 0.05 , and has a positive direction, this is in accordance with the hypothesized direction. Therefore, this results indicates that H1 is accepted. The table shows that the firm size variable (FS) shows a probability significance number above 0.05 which means that firm size variables have a positive relationship to operational performance. In other words, the hypothesis H2 is accepted. In hypotesis 3 the table shows that the no significance value of strategy variables because the number is greater than 0.05 , which means that the strategy has no effect on the operational performance of MSMEs. This shows that H3 hypothesis is not accepted. The results of research showsthe proxy application of technology and firm sizewhich can be proven empirically have the direction of influence according to the hypothesized, strategy is in the contrary to the hypothesized. For Determination Coefficient Test indicates that the adjusted value of R2 is 0.856 or $85.6 \%$ which that $85.6 \%$ dependent variable of operational performance is influenced by independent variables; application of technology, firm size and strategy. While the rest is explained by other variables that are not included in the study.

\section{Discussion:}

Influence Variable Application of Technology to Operational Perfomance:

Hypothesis 1 stated that the application of technology has an influence on the operational performance of MSMEs. Based on the results of questionnaires, on average of 33 respondents who applied technology on business activities produce high operational performance of the business. This can be seen from the total score for the application of technology which has a maximum score of 4.15 and the minimum score is 3.76 . This indicates that investment in technology is a difference of 0.39 resulting in a small score difference, so investment in technology has an influence on the operational performance of MSMEs in East Jakarta. this result is supported from the data of respondents who have been mostly used the technology of computers, and from the analysis of the answers note that the 
majority of respondents agree if the use of technology can improve the effectiveness of the business and allow the perform tasks easier, so the target of the business is fulfilled more effectively. With this condition respondents are always motivated to investigate in technology.This research is in line with the research of Moorthy et al [45] and Ashrafi and Murtaza (2008) which claimed there is a relationship between the application of technology to performance.

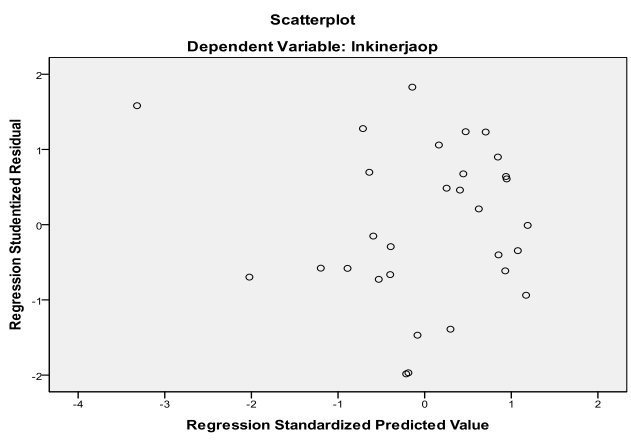

Fig. 3:

Influence Variable Firm Size to Operational Perfomance:

A second hypothesis which stated that firm size has an effect on operational performance is accepted. Therefore, it can be concluded that the partial variable firm size (X2) affect the variable operational performance. Based on the data that has been obtained, it is known that from 33 respondents has the total score 20.29for the maximum company size and 14.91 for the minimum score. This indicates that there is a margin of 5.38 the range is small, so the firm size has effect on the operational performance of MSMEs in East Jakarta.This result is supported from the average data of assets owned by respondents that is about IDR. $142,424,242$, but with the limited asset they can optimized operational performanceamong others to achieve the company's goals, to get high profit. This research is in line with Monteiro [30], Dogan [20] Pervan and Visic which stated the size of the company has a significant influence on export performance.

\section{Influence of Strategic Variables on Operational Perfomance:}

The third hypothesis in this study is the strategy affect the operational performance. Based on the results of research that has been done, it is proved that this hypothesis is not accepted. Therefore, it can be concluded that partially there is no positive and significant influence between strategy variable (X3) on operational performance variable (Y). Based on the data that has been obtained, it is known from 33 respondents with above average strategies such as high performance of business operations and the rest have low performance. Based on the calculation results shows the total score for the maximum strategy is 4.24 and the minimum score is 3.82. This indicates that the investment in technology is 0.42 difference which resulted in the difference of score which is not too big and gives negative relation result to operational performance, so the strategy has on effect to the operational performance of MSMES in East Jakarta.From previously distributed questionnaires, it is known that the majority of respondents have shown the implementation of strategy in MSMEs in East Jakarta. They agreed that operational performance could be accomplished by decreasing costs, improving product quality, increasing customer preference and raising competing quality, but in fact it provides value in the opposite direction to theory and does not show the relationship between strategy and operational performance. This is possible because of the implementation of the strategy can be less precise, so there is needs to be assisted to implement the business strategy, in accordance with the needs of MSMEs. This research is not in line with the research Hasan dan Ogundipe [23] Khrisna et al., Gilaninia et al., [22].

\section{Conclusions and Recommendations:}

Based on the results of research and the discussion, the researchers concluded that the application of technology has an effect on the accountability of MSMES operational performance. The hypothesis 2, the Form size has an effect on operational performance is not accepted. Therefore, it can be concluded that the partial variable Firm size (X2) affect the variable operational performance. The hypothesis 3, there is no positive and significant influence between strategy variable (X3) on operational performance variable $(\mathrm{Y})$. With the limitation of the research, the researcher can give suggestion for subsequent research to expand sample of research, and should use variable of factors influencing accountability of operational performance which can explain and influence significantly toward the performance variable of MSMES, for example understanding to system accounting, access to working capital, etc. Furthermore, it is also expected to develop the use of proxies that exist in this research variables, both dependent and independent variables, such as proxy for firm size replaced by other poxies,suc as the number of employees.

\section{ACKNOWLEDGEMENT}

I thank Dr.Dedi Purwama, MBus, Dr. Ari Saptono MPd, Setyo Ferry W, Msi, Dr. Yasser Arafat, MM, Unggul Poerwohedi Phd, Dr.Suherman,Msi for support both material and non material.

[1] Anas Abrar, Herri, Syafrudin Karimri, 2005. Analysis Of Corporate Factors Affecting Export Performance (Case Study Of Export Companies In West Sumatra). Journal Of Business And Management, 1.

[2] Prabowo Harry Anggraini Zr, Ratna, Tresno Ej, 2015. Management Accounting Information System, Strategy, Innovation And The Influence To Operating Performance Of Companies Manufacturing Of Indonesia: Entering The Free Trade Era. Proceeding Internal Conference, Apcaf, Bali-Indonesia.

[3] Yohan, Anggraini Ratna Z.R., Etty Guredrawati, 2015. Firm Size, Ownership Concentration And Business Sector: The Influence To Credit Access MSMEs In Indonesia. International Journal Of Finance And Accounting, 4(5).

[4] Reich, B.H., I. Benbasat, M. Information and S. Division, 1999. "Factors That Influence The Social Dimension Of Alignment Between Business And Information Factors That Influence The Social Dimension Of Alignment Between Business And Information Technology Objectives, $604:$ 1-59.

[5] Cristianto Henry, Riri Satria, Yudho Giri Sucahyo, 2007. Influence Of Information System / Information Technology Implementation To Company's Operational Performance: Case Study Of Delivery Service Company. Jurnal. Mti. Ui., 3(2).

[6] Dirgantoro, Crown, 2004. Strategic Management. Jakarta: Pt. Grasindo.

[7] Fahmi, Irham, 2010. Performance Management. Bandung: Alfabeta.

[8] Ghozali, Imam, 2011. Application of Multivariate Analysis With Spss Program. Semarang: Bp Universitas Diponegoro.

[9] Hansen and Mowen, 2005. Management Accounting. Jakarta: Salemba Four.

[10] Hill, H., 2001. Small And Medium Enterprise In Indonesia: Old Policy Challenges For The New Administration. Asian Survey, 41: 248-270.

[11] Hope, Thomas and Vyas, 2009. Transparency, Ownership and Financing Constraints In Private Firms.

[12] Http://Www.Artikelteknologi.Com/2015/05/Definisi-Teknologi-Dan-Pengertian-Teknologi.Html.Diunduh November 2016-11-03.

[13] Hu, X. and F. Schiantarelli, 1994. Investment And Financing Constraints: A Switching Regression Approach Using Firm Level Data Panel.

[14] Indriantoro, Nur and Supomo, 1999. Business Research Methodology for Accounting \& Management, Bpfe Yogyakarta.

[15] Isachenkova, N. and Tomasz Mickiewicz, 2004. Financial Constraints and Corporate Control Structures: Evidence From A Survey of Large Companies In Hungary and Poland.

[16] Kodrat, David Sukardi, 2009. Management Strategy. Yogyakarta: GrahaIlmu.

[17] Mangkunegara, Anwar Prabu, 2005. Performance Evaluation. Bandung: Refikaaditama. 
14(3): 18-22.

[18] Ashrafi, R. and M. Murtaza, 2008. Use And Impact Of Ict On MSMEs In Oman. The Electronic Journal Information Systems, 11.

[19] Author Links Open Overlay Panelerkanbayraktaramehmetdemirbagbs. C. Lennykohbekremtatogluchalilzaimd

[20] Dogan, M., 2013. Does Frm Size Frm Proftability Affect? Evidence Turkey. Research Journal Of Finance And Accounting, 4(4): 53-59.

[21] Gibcus, P. and R. Kemp, 2003. Strategy And Small Firm Performance, Research Report H200208, January, Eim, Zoetermeer.

[22] Gilaninia, S. and S.J. Mousavian, 2012. The Role of Ict In Performance Of Small And Medium Enterprises.Research In Interdisciplinary Journal Of Contemporary Research In Business, January, 3(9).

[23] Hassan, Hannatu and Ogundipe, Adeyemi, Ict Adoption By Micro And Small Scale Enterprises In Nigeria: A Case Study Of The Federal Capital Territory, Abuja (April 12, 2017). Available At Ssrn: Https://Ssrn.Com/Abstract=2951901 Or Http://Dx.Doi.Org/10.2139/Ssrn.2951901.

[24] Https://Finance.Detik.Com/Berita-Ekonomi-Bisnis/3350243/Umkm-Serap-57\%,Diakses 10 Februari 2018.

[25] Https://Www.Sciencedirect.Com/Journal/International-Journal-Of-Production-Economics Innovation And The Operational Performance Of Newly Established Small And Medium Enterprises In Taiwan.

[26] Jung E. Ha-Brookshire, 2009. "Does The Firm Size Matter On Firm Entrepreneurship And Performance?: Us Apparel Import Intermediary Case", Journal Of Small Business And Enterprise Development, 16(1):132-146, Https://Doi.Org/10.1108/14626000910932926.

[27] Kaplan, R.S. and D.P. Norton, 1992. The Balance Scorecard Measure That Drive Performance. Harvard Business Review, 3: 71-79.

[28] Leitner, Kh. and Güldenberg, S. Small Bus Econ, 2010. 35: 169. Https://Doi.Org/10.1007/S11187-009-9239-X.Accesed February 12 th 2018.

[29] Leong, G., D.L. Snyder and Ward, Peter, 1990. Research In The Process And Content Of Manufacturing Strategy. Omega. 18. 109-122. 10.1016/03050483(90)90058-H.

[30] Monteiro, M.C., Tatiana, Moreira, Maria and Sousa, Paulo, 2013. Relationship Between Firm Size And Export Performance: An Exploratory Analysis. Economics And Management Research Projects: An International Journal, 3: 9-23.

[31] Manurung, Laurensius, 2010. Strategy And Innovation Business Model Improve Business Performance. Jakarta: Pt. Elex Media Komputindo.

[32] Mukti, ArifinMukti, Sri Lestari and Devani LaksmiIndyastuti. Influence of Innovation Strategy On Operational Performance Of Exhaust Industry In Purbalingga Regency, Journal Of Feb Unsoed.

[33] Rita Influence Innovation Strategy To Operational Performance Manufacturing Company, Binus Business Riview, Vol.1. November 2, 2010.Repository.Widyatama.Ac.Id/Xmlui/Bitstream/Handle/123456789/,Diunduh November 2016-11-03,

[34] Samir Alfin Dan Dwi Larso, Identify Factors Affecting The Performance Of MSMEs Catering In Bandung. Journal Of Technology Management.

[35] Samryn, L.M., 2011. Pengantarakuntansi. Jakarta: Rajawali Pers.

[36] Setyobudi, Andang, 2007. Bank Indonesia's Role In The Development Of Micro, Small And Medium Enterprises (Umkm), Bulletin Of Banking And Financial Law, 5: 29-35.

[37] Simanjuntak, Payaman J., 2005. Management and Performance Evaluation. Jakarta: Institution Publisher Faculty Of Economics Of Indonesia University.

[38] Sudarmanto, 2009. Performance and Competence Development. Yogyakarta: Student Libraries.

[39] Sugiyono, 2007. Educational Research Methods Quantitative Approach, Qualitative, And R \& D. Bandung: Alfabeta.

[40] Supratikno, Hendrawan, 2006. Performance Management To Create Competitive Advantage. Yogyakarta: Graha Science.

[41] Tika, P., 2006. Organization Culture and Corporate Performance Improvement. Jakarta: Pt. Bumiaksara.

[42] Umar, Husayn, 2005. Company Performance Evaluation. Jakarta: Gramedia Main Library.

[43] Umar, Husayn, 2010. Strategic Management Research Design. Jakarta: Rajawali Pers.

[44] Wibowo, 2013. Performance Management. Jakarta: Rajawali Pers.

[45] Moorthy M. Krishna, Annie Tan, Caroline Choo, Chang Sue Wei, Jonathan Tan Yong Ping and Tan Kah Leong, 2012. A Study On Factors Affecting The Performance Of MSMEsIn Malaysia. International Journal Of Academic Research In Business And Social Sciences, 2(4).

[46] Nehemiah, W., 2017. Supply Chain Management Practices And Operational Performance Of MSMEs In Nairobi County, Kenya. In: Achtenhagen L., Brundin E. (Eds) Management Challenges In Different Types Of African Firms. Frontiers In African Business Research. Springer, Singapore.

[47] Porter, Michael E., 1985. "Competitive Advantage". 1: 11-15. The Free Press. New York.

[48] Raziq, Abdul, 2014. The Relationship Between Firm Size And High Performance Management Practices In Pakistani MSMEs. Indian Journal of Commerce And Management Studies, 5: 27-36.

[49] Gnyawali, D., B. Park, 2009. Co-OpetitionAnd Technological Innovation In Small And Medium Enterprises: A Conceptual Multilevel Model, Journal Of Small Business Management, 47: 308-330.

[50] Wiesner, R., B. Millett, 2012. Strategic Approaches In Australian MSMEs: Deliberate Or Emergent? Journal Of Management \& Organization, 18(1): 98-122. Doi:10.1017/S1833367200001097. Accesed February 13th 2018.

[51] https://www.cnnindonesia.com/ekonomi/20161121122525-92-174080/kontribusi-umkm-terhadap-pdb-tembus-lebih-dari-60-persen 